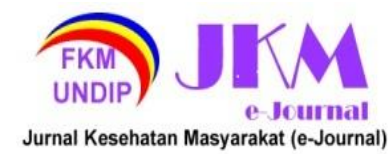

JURNAL KESEHATAN MASYARAKAT (e-Journal)

Volume 10, Nomor 1, Januari 2022

ISSN: 2715-5617 / e-ISSN: 2356-3346

http://ejournal3.undip.ac.id/index.php/ikm

\title{
FAKTOR-FAKTOR YANG BERHUBUNGAN DENGAN KINERJA PEGAWAI PUSKESMAS SRAGEN PADA MASA PANDEMI COVID-19
}

\author{
Galuh Wulansari ${ }^{1 *}$, Bambang Wahyono ${ }^{1}$ \\ ${ }^{1}$ Jurusan Ilmu Kesehatan Masyarakat Universitas Negeri Semarang, \\ Gedung F5, Kampus Sekarang, Gunung pati, Kota Semarang \\ *Corresponding author: galuhwulansari@students.unnes.ac.id
}

\begin{abstract}
The Covid-19 incident has impact on decline in performance of health services, one of which is the role of health center in carrying out their duties and functions. The performance achievement at Sragen Health Center of $65.62 \%$ is included in less category, it is proven that it does not reach the government's target of $80 \%$. This type of research is quantitative with cross sectional study. The population in this study were all employees of the Sragen Public Health Center. The sample was 56 respondents with a total sampling technique. The research instrument used in the form of questionnaires and documentation. Data were analyzed by chi-square test using SPSS 16.0. Variables related to employee performance in this study were attitude $(p=0.002, R P=3.60$, $C I(95 \%)=1.59-8.12)$, motivation $(p=0.001, R P=7,72, C I(95 \%)=2.52-23.6)$, work experience $(p=0.001$, $R P=6.45, C I(95 \%)=1.63-25.44)$, environment $(p=0.002, R P=3.6, C I(95 \%)=1.59-8.12)$. There needs to be an effort that can improve attitudes and motivation of employees by giving appreciation for their work. In addition, agencies need to provide training to increase the knowledge and skills of employees in their work as well as complete work facilities which are expected to improve the performance of employees at the Sragen Health Center.
\end{abstract}

Keywords: performance, environment, motivation, experience, attitude

\section{PENDAHULUAN}

World Health Organization (WHO) menyatakan wabah penyakit akibat Covid-19 sebagai pandemi global. ${ }^{1}$ Dinyatakannya status ini diakibatkan kasus terkonfirmasi positif di luar China yang meningkat tiga belas kali lipat di 200 negara dengan total mengatasi penyebaran virus Covid-19 ini. Hampir lebih dari 200 negara diperkirakan terjangkit virus ini. Salah satunya adalah negara Indonesia. Tingginya tingkat kematian akibat Covid-19 ini dipengaruhi oleh keberadaan penyakit penyerta yang dimiliki oleh pasien positif, usia rentan serta fasilitas kesehatan yang kurang memadai. ${ }^{2}$ Selain itu, banyaknya jumlah kematian yang bertambah hari demi hari akibat Covid-19 ini tidak hanya menimbulkan gejala dan penyakit fisik saja, akan tetapi berpengaruh besar terhadap kesejahteraan masyarakat Indonesia yang salah satunya berdampak pada sektor kesehatan.

Salah satu sektor kesehatan yang terdampak pandemi Covid-19 adalah Puskesmas Sragen. Berdasarkan hasil observasi wawancara kepada penanggung jawab kegiatan program di Puskesmas Sragen, terbukti bahwa banyak program kerja di Puskesmas Sragen pada tahun 2020 yang cakupan kinerja masih rendah diantaranya adalah rendahnya kinerja cakupan upaya kesehatan masyarakat essensial dengan rata-rata kinerja sebesar $61,51 \%$, cakupan kinerja upaya kesehatan masyarakat pengembangan dengan rerata kinerja sebesar 56,35\%, dan cakupan upaya kesehatan perorangan laboratorium dan kefarmasian dengan rerata kinerja sebesar 94,2\%. Sehingga diperoleh nilai kinerja cakupan pelayanan kesehatan Puskesmas Sragen tahun 2020 sebesar 65,62\% yang masuk dalam kategori "kurang". Hal tersebut terbukti belum mencapai target Pemerintah sebesar $80 \%$ berdasarkan Standar Pelayanan Minimal Kesehatan PERMENKES No. 4 Tahun 2019. Disamping itu, banyak program-program kerja yang rutin dilaksanakan setiap tahunnya, pada tahun 2020 diberhentikan. Program-program kerja yang terkendala tersebut antara lain Posbindu PTM (Penyakit Tidak Menular), Posyandu, serta Pemantauan Jentik Berkala (PJB). Disamping itu, masalah kesehatan PTM serta Demam Berdarah Dengue tersebut belum dapat diatasi secara tuntas. Hal itu terjadi karena banyak program kerja dari pemerintah yang lebih menfokuskan pada penanggulangan pandemi Covid-19.

Kinerja pegawai dalam sebuah organisasi memang memiliki pengaruh positif terhadap pencapaian visi dan misi sebuah organisasi. Kinerja seorang karyawan merupakan suatu hal yang sangat penting karena berkaitan dengan hasil dan keberhasilan sebuah organisasi. ${ }^{3}$ Berdasarkan teori Gibson mengemukakan bahwa faktor yang mempengaruhi kinerja terbagi menjadi 3 faktor, yakni faktor yang berasal dari individu terdiri dari umur, jenis kelamin, pengalaman kerja. ${ }^{4}$ Kemudian faktor psikologis yang terdiri dari sikap, disiplin, dan motivasi. ${ }^{5}$ Faktor dalam organisasi yang terdiri dari kepemimpinan, imbalan, struktur 


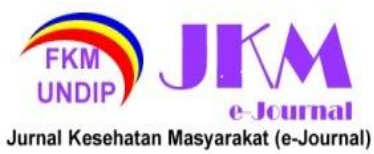

keorganisasian dan supervisi. Faktor yang mempengaruhi kinerja karyawan yaitu kemampuan karyawan, dukungan organisasi, motivasi dan evaluasi karyawan. Berdasarkan beberapa kajian dan penelitian mengenai teori tersebut serta beberapa penelitian terkait. Peneliti menyederhanakan faktor-faktor yang berhubungan dengan kinerja pegawai diantaranya adalah sikap kerja, motivasi kerja, pengalaman kerja dan lingkungan kerja.

Beberapa hal yang membedakan penelitian ini dengan penelitian-penelitian sebelumnya adalah lokasi penelitian yang dilakukan di Puskesmas Sragen, Kabupaten Sragen. Puskesmas Sragen merupakan salah satu puskesmas yang terdampak akibat pandemi Covid19. Berdasarkan laporan resmi sragen tanggap Covid-19, kasus Covid-19 di wilayah kerja Puskesmas Sragen merupakan salah satu penyumbang kasus tertinggi se-Kabupaten Sragen. Hal itu terbukti berdampak pada penurunan capaian kinerja di Puskesmas Sragen pada tahun 2020.

Berdasarkan uraian diatas, peneliti bertujuan untuk mengetahui faktor-faktor yang berhubungan dengan kinerja pegawai Puskesmas Sragen pada masa pandemi Covid-19 tahun 2021

\section{METODE PENELITIAN}

Penelitian ini merupakan jenis penelitian kuantitatif dengan pendekatan cross-sectional study. Populasi dalam penelitian ini adalah seluruh pegawai Puskesmas Sragen. Besar sample menggunakan teknik total sampling sehingga diperoleh 56 sampel. Instrumen dalam penelitian ini menggunakan kuesioner yang terdiri dari. variabel bebas diantaranya sikap kerja, motivasi kerja, pengalaman kerja dan lingkungan kerja. sedangkan variabel terikatnya yaitu kinerja pegawai.

Sumber data dalam penelitian ini diperoleh dari data primer melalui data pengisian kuesioner dan dokumentasi dan data sekunder penelitian yang diperoleh melalui data capaian kinerja Puskesmas Sragen tahun 2020. Analisis data dalam penelitian ini menggunakan analisis univariat dan bivariat. Analisis data bivariat menggunakan menggunakan uji chi-square menggunakan SPSS 16.0. Jika nilai $\mathrm{p}>0,05$, maka $\mathrm{H}_{\mathrm{o}}$ diterima dan $\mathrm{H}_{\mathrm{a}}$ ditolak yang artinya secara statistik variabel tersebut tidak memiliki hubungan yang signifikan terhadap variabel terikat dan begitu pula sebaliknya. Apabila nilai $\mathrm{p}<0,05 \mathrm{H}_{\mathrm{o}}$ ditolak dan $\mathrm{H}_{\mathrm{a}}$ diterima maka variabel tersebut memiliki hubungan yang signifikan dengan variabel terikat.

\section{HASIL DAN PEMBAHASAN}

Tabel 1. Hubungan antara sikap kerja dengan kinerja

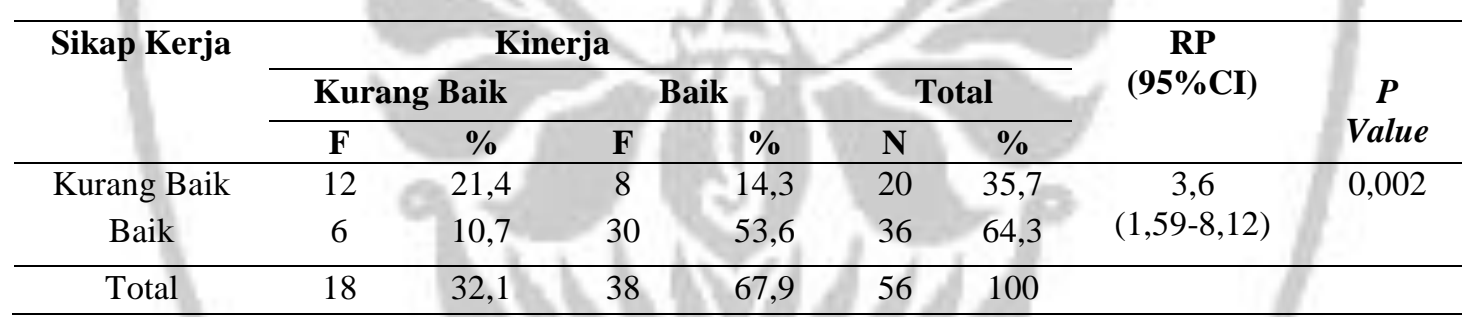

Berdasarkan tabel 1 diatas pengujian hubungan sikap kerja dengan kinerja dengan uji chi-square diketahui bahwa nilai $p$-value diperoleh nilai sebesar 0,002. Karena nilai p-value $<0,05$ $(0,002<0,05)$, maka keputusannya adalah menolak $\mathrm{H}_{0}$, dan menerima $\mathrm{H}_{\mathrm{a}}$. Maka dapat ditarik kesimpulan bahwa terhadap hubungan yang bermakna antara variabel sikap kerja dengan kinerja. Pegawai yang memiliki sikap kerja kurang baik lebih berisiko 3,6 kali mempunyai kinerja kurang baik dibandingkan pegawai yang memiliki sikap kerja baik. Selain itu, diperoleh nilai korelasi Pearson sebesar 0,445, sehingga dapat disimpulkan bahwa terdapat korelasi positif searah dengan kekuatan korelasi yang sedang. Korelasi positif dapat diartikan bahwa dengan semakin baik sikap kerja pegawai, maka semakin baik kinerja pegawai.

Hasil tersebut didukung oleh teori Azwar bahwa sikap kerja terdiri dari tiga aspek diantaranya (1) aspek kognitif, aspek ini memberikan sebuah respresentasi dalam menanggapi mengenai fenomena-fenomena atau masalah-masalah yang muncul yang kemudian seorang pegawai memberikan sebuah sikap yang sesuai dalam menyikapi masalah baru, (2) aspek konatif yang bersangkutan dengan diri pegawai. Dalam hal ini, terkait dengan pengetahuan dan ketrampilan yang dimiliki seorang pegawai dan (3) aspek afektif yang berupa tendensi atau kecenderungan seorang pegawai untuk bertindak sesuatu. ${ }^{6}$

Hasil ini sesuai dengan penelitian sebelumnya yang dilakukan oleh Ahmad Kholis Zamroni, penelitian tersebut membuktikan bahwa sikap kerja memiliki pengaruh terhadap kinerja karyawan. Dalam penelitian tersebut diperoleh hasil uji statistik yang menunjukkan nilai signifikasi sikap kerja dengan $p$-value sebesar $0,042(0,042<0,05)$, maka dapat dikatakan bahwa 


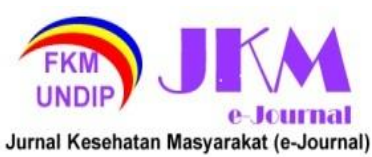

sikap kerja secara statistik berpengaruh positif dan signifikan terhadap kinerja karyawa. ${ }^{7}$

Berdasarkan data hasil penelitian per indikator sikap kerja dengan kinerja pegawai terhadap 56 responden yang ada di Puskesmas Sragen menunjukkan bahwa sikap kerja dan kinerja masing-masing diperoleh prosentase sebesar 64,3\% dan $67,9 \%$ yang masuk dalam kategori baik. Sedangkan, sikap kerja dan kinerja masing-masing dengan prosentase $35,7 \%$ dan $32,1 \%$ dan masuk dalam kategori kurang baik.

Sikap kerja seorang tenaga kesehatan di era pandemi Covid-19 ini dituntut dalam memberikan pelayanan yang optimal, cepat dan tanggap serta mencerminkan sikap yang menjujung tinggi profesionalisme dalam memberikan pelayanan kepada masyarakat. Selain itu, seorang tenaga kesehatan perlu adanya inisiatif dan inovatif dalam menyelesaikan tugasnya guna mencapai target kinerja yang diharapkan oleh sebuah organisasi. Di era pandemi Covid-19 ini, untuk meningkatkan kualitas dalam pelayanan serta mengantisipasi segala dampak pembangunan, penting dibuat inovasi baru dalam menanggulangi dan menghadapi masalah-masalah baru yang timbul.

Tabel 2. Hubungan antara motivasi kerja dengan kinerja

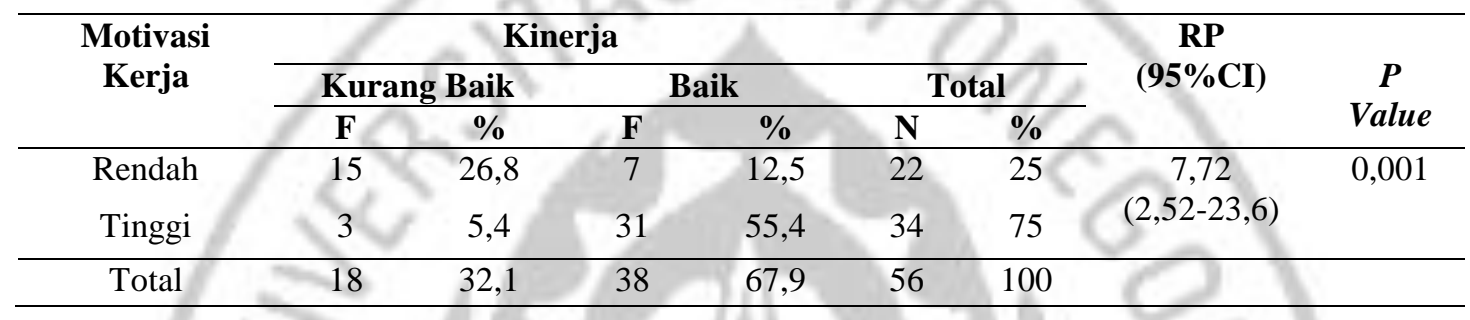

Berdasarkan tabel 2 diatas pengujian hubungan motivasi kerja dengan kinerja dengan uji chi-square diketahui nilai $p$-value diperoleh nilai sebesar 0,001. Karena nilai p-value $<0,05$ $(0,001<0,05)$, maka keputusannya adalah menolak $\mathrm{H}_{0}$, dan menerima $\mathrm{H}_{\mathrm{a}}$. Maka dapat ditarik kesimpulan bahwa terhadap hubungan yang bermakna antara variabel motivasi kerja dengan kinerja. Pegawai yang memiliki motivasi kerja yang rendah lebih berisiko 7,72 kali mempunyai kinerja kurang baik dibandingkan pegawai yang memiliki motivasi kerja tinggi. Diperoleh nilai korelasi Pearson variabel motivasi kerja terhadap variabel kinerja sebesar 0,621, sehingga dapat disimpulkan bahwa terdapat korelasi positif searah dengan kekuatan korelasi yang kuat. Korelasi positif dapat diartikan bahwa dengan semakin tinggi motivasi kerja pegawai, maka semakin baik kinerja pegawai.

Hasil penelitian ini sejalan dengan penelitian sebelumnya oleh Hernika terkait dengan faktor-faktor yang berhubungan dengan kinerja. Penelitian tersebut membuktikan bahwa motivasi kerja memiliki hubungan dengan kinerja seorang pegawai. ${ }^{8}$ Selain itu, peneliti lain Latifah Isnaini Fauzi, juga membuktikan bahwa motivasi kerja memiliki korelasi positif dan memiliki hubungan yang signifikan dengan kinerja pegawai. ${ }^{9}$ Penelitian ini juga diperkuat oleh hasil penelitian Hari Mulyadi yang mana hasil penelitiannya menunjukkan adanya korelasi motivasi terhadap kinerja karyawan dan keduanya memiliki hubungan yang kuat dalam peningkatan kinerja seorang karyawan dalam menjalankan tugasnya.
Dalam penelitian ini sejalan dengan teori motivasi dari Suhartini yang mengemukakan bahwa indikator dalam motivasi terdiri dari penghargaan, pengakuan, kesempatan, dan berkembang. Seorang tenaga kesehatan akan memiliki motivasi tinggi apabila dalam sebuah organisasi memberikan sebuah penghargaan. Penghargaan dimaksudkan guna memberikan apresiasi bagi seorang pegawai atas kemampuannya dalam melaksanakan tugasnya agar tetap baik dan stabil. Pengakuan juga memiliki faktor besar dari timbulnya sebuah motivasi yang baik. Ketika seorang pegawai mendapatkan pengakuan maka secara langsung pegawai tersebut akan merasa dihargai dan pegawai tersebut akan mempunyai dorongan untuk lebih berprestasi dalam pekerjaannya. Selain itu, kesempatan dan berkembang merupakan indikator penting dalam motivasi. Dengan adanya kesempatan dan berkembang yang diberikan oleh atasan kepada pegawai, maka pegawai akan bekerja lebih keras lagi untuk terus maju. Di era pandemi Covid-19 ini, seorang tenaga kesehatan dituntut untuk bekerja lebih optimal. Oleh karena itu, penting untuk memberikan insentif kepada tenaga kesehatan guna balas jasa atas usaha maksimal yang dilakukan oleh tenaga kesehatan dalam memberikan pelayanan di situasi pandemi Covid-19 ini. Dengan adanya pemberian insentif ini, diharapkan tenaga kesehatan lebih termotivasi tinggi untuk bekerja dan semangat pada dirinya.

Disamping itu, data hasil penelitian per indikator motivasi kerja dengan kinerja pegawai terhadap 56 responden yang ada di Puskesmas 


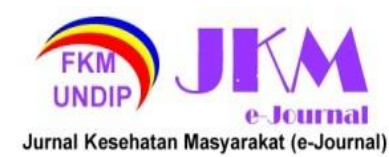

Sragen menunjukkan bahwa motivasi kerja dan kinerja masing-masing diperoleh prosentase sebesar $60,7 \%$ dan $67,9 \%$ masuk dalam kategori tinggi dan baik. Sedangkan, motivasi kerja dan kinerja masing-masing dengan prosentase 39,3\% dan $32,1 \%$ masuk dalam kategori rendah dan kurang baik.

Berdasarkan hasil tersebut dapat diketahui pula bahwa motivasi kerja seorang tenaga kesehatan adalah faktor penting dalam peningkatan sebuah kinerja. Seorang tenaga kesehatan yang termotivasi dalam bekerja akan mampu mencapai kinerja yang baik dan optimal. Kinerja yang baik seorang tenaga kesehatan merupakan sebuah langkah untuk tercapainya visi dan misi sebuah organisasi. ${ }^{10}$ Motivasi seorang tenaga kesehatan merupakan faktor penting bagi kinerja tenaga kesehatan dalam mewujudkan target dalam organisasi. Karena dengan motivasi pegawai yang tinggi, maka kinerja pegawai juga turut meningkat. Begitu pula sebaliknya apabila motivasi pegawai rendah maka kinerja pegawai juga turut menurun yang akan berpengaruh terhadap organisasi tersebut. Hal tersebut mendukung bahwa pegawai yang memiliki motivasi rendah, maka tidak akan mencapai target kerja yang diinginkan. Sebaliknya, apabila pegawai yang memiliki motivasi yang tinggi, maka target dalam organisasi akan mudah dicapai.

\section{Tabel 3. Hubungan antara pengalaman kerja} dengan kinerja.

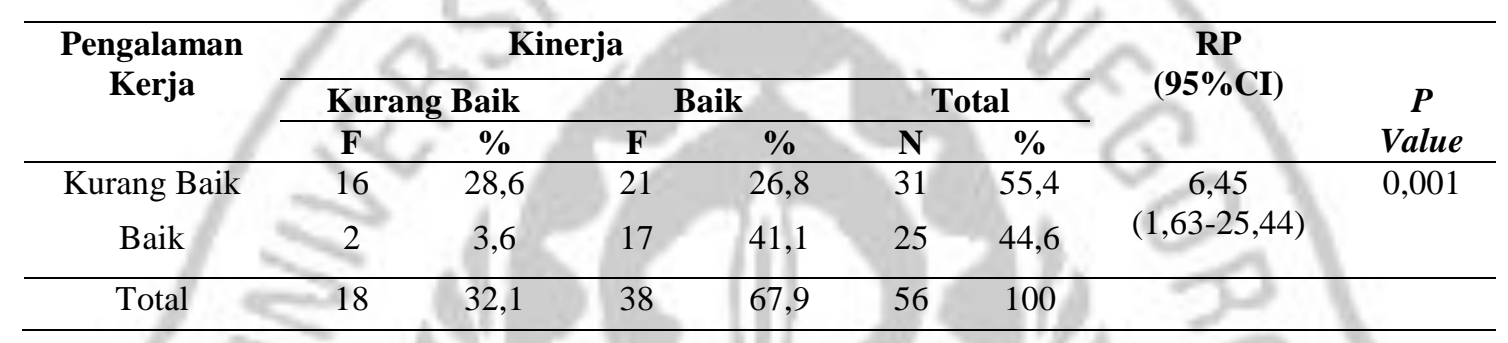

Berdasarkan tabel 3 pada pengujian hubungan pengalaman kerja dengan kinerja dengan uji chi-square diketahui nilai $p$-value diperoleh nilai sebesar 0,001. Karena nilai p-value $<0,05$ $(0,001<0,05)$, maka keputusannya adalah menolak $\mathrm{H}_{0}$, dan menerima $\mathrm{H}_{\mathrm{a}}$. Maka dapat ditarik kesimpulan bahwa terhadap hubungan yang bermakna antara variabel pengalaman kerja dengan kinerja. Pegawai yang memiliki pengalaman kerja kurang baik lebih berisiko 6,45 kali mempunyai kinerja kurang baik dibandingkan pegawai yang memiliki pengalaman kerja baik. Selain itu, diperoleh nilai korelasi Pearson pengalaman kerja terhadap kinerja sebesar 0,612, sehingga dapat disimpulkan bahwa terdapat korelasi positif searah dengan kekuatan korelasi yang kuat. Korelasi positif dapat diartikan bahwa dengan semakin baik pengalaman kerja pegawai, maka semakin baik kinerja pegawai.

Hasil penelitian ini sesuai dengan penelitian sebelumnya yang dilakukan oleh Jefrison terkait faktor-faktor yang berhubungan dengan kinerja pegawai di Puskesmas Pariaman. Dalam penelitian tersebut membuktikan bahwa pengalaman kerja memiliki hubungan dengan kinerja pegawai Puskesmas. ${ }^{11}$ Penelitian ini juga sesuai dengan penelitian yang dilakukan Latifah Isnaini Fauzi, berdasarkan hasil uji statistik menunjukkan bahwa terdapat pengaruh positif dan signifikan antara pengalaman kerja terhadap kinerja dan korelasi product moment yang kuat. ${ }^{9}$
Hasil dalam penelitian ini sesuai dengan teori pengalaman dari Foster Bill. Bill mengemukakan bahwa indikator pengalaman kerja terdiri dari lamanya masa kerja, pengetahuan dan keterampilan serta penguasaan terhadap peralatan dan pekerjaan seorang pegawai. $^{12}$ Pengaruh pengalaman kerja di masa pandemi Covid-19 terhadap kinerja pegawai dapat dijelaskan dengan beberapa faktor yang ada seperti lama waktu seseorang bekerja sangat berpengaruh dan hal penting peranannya dalam meningkatkan kinerja pegawai, ketika pegawai sudah lama bekerja pada bidangnya maka pegawai akan lebih cepat dalam memahami tugas-tugas dengan baik. Dalam kaitannya dengan kejadian pandemi Covid-19, pegawai yang memiliki pengalaman kerja lebih lama maka akan lebih paham dalam mengatasi permasalahan dan lebih meminimalisir tingkat kesalahannya dalam menyelesaikan tugasnya tersebut. Tingkatan pengetahuan dan ketrampilan juga berpengaruh dengan kinerja, pegawai yang baru akan lebih cenderung mengalami kesulitan dalam memahami pekerjaannya, sedangkan pegawai yang lama akan lebih terampil dan mumpuni membantu pegawai lain dalam menciptakan keefisienan dan keefektifan penggunaan waktu serta penguasaan terhadap pekerjaannya.

Faktor lain yang mempengaruhi pada penelitian ini adalah pengalaman kerja sebagian tenaga kesehatan di masa pandemi Covid-19 ini dapat membantu mengurangi kesalahan dalam 


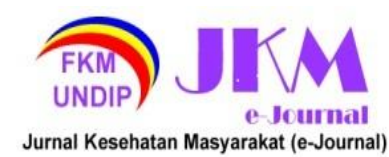

menyelesaikan tugas dan pekerjaan untuk mencapai visi dan misi organisasinya. Hal tersebut didukung oleh hasil penelitian ini yang diperoleh 44,6\% responden menyatakan bahwa pengalaman kerja pegawai menilai sudah baik dan $55,4 \%$ responden menyatakan bahwa pengalaman kerja menilai kurang baik. Oleh karena itu, indikator pengalaman
JURNAL KESEHATAN MASYARAKAT (e-Journal)

Volume 10, Nomor 1, Januari 2022

ISSN: 2715-5617 / e-ISSN: 2356-3346

http://ejournal3.undip.ac.id/index.php/ikm

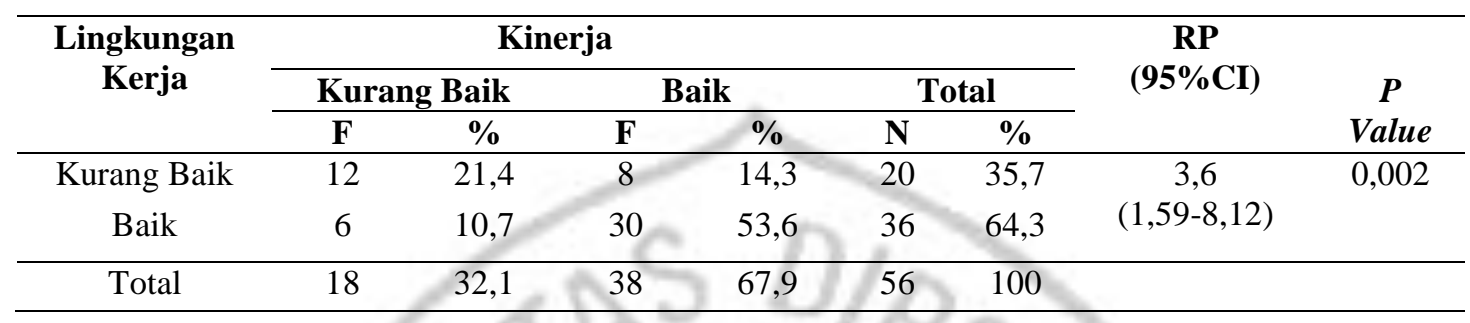

Berdasarkan tabel 4 diatas pada pengujian hubungan lingkungan kerja dengan kinerja dengan uji chi-square diketahui nilai $p$-value diperoleh nilai sebesar 0,002 . Karena nilai p-value $<0,05$ $(0,002<0,05)$, maka keputusannya adalah menolak $\mathrm{H}_{0}$, dan menerima $\mathrm{H}_{\mathrm{a}}$. Maka dapat ditarik kesimpulan bahwa terhadap hubungan yang bermakna antara variabel lingkungan kerja dengan kinerja. Pegawai yang menilai lingkungan kerja kurang baik lebih berisiko 3,6 kali mempunyai kinerja kurang baik dibandingkan pegawai yang menilai lingkungan kerja baik. Selain itu, diperoleh nilai korelasi Pearson variabel lingkungan kerja terhadap variabel kinerja sebesar 0,445 , sehingga dapat disimpulkan bahwa terdapat korelasi positif searah dengan kekuatan korelasi yang sedang. Korelasi positif dapat diartikan bahwa dengan semakin baik lingkungan kerja pegawai, maka semakin baik kinerja pegawai.

Hasil penelitian ini sesuai dengan penelitian sebelumnya yang dilakukan oleh Ahmad Kholis Zamroni, penelitian tersebut membuktikan bahwa lingkungan kerja memiliki pengaruh yang signifikan terhadap kinerja karyawan. Sikap kerja secara statistik berpengaruh positif dan signifikan terhadap kinerja karyawan. ${ }^{7}$ Selain itu, penelitian lain oleh Daniel Surjosuseno juga menunjukkan bahwa lingkungan kerja berpengaruh positif dan signifikan pula terhadap kinerja karyawan. ${ }^{13}$ Selain itu, hal tersebut sesuai dengan teori Nitisemito bahwa suatu kondisi lingkungan kerja dapat dikatakan baik apabila pegawai dapat melaksanakan kegiatan secara optimal, sehat, aman dan nyaman sedangkan lingkungan kerja yang tidak memadai menuntut pegawai dan waktu yang lebih banyak dan tidak mendukung diperolehnya rancangan sistem kerja yang efisien.

Lingkungan kerja yang nyaman akan secara langsung berdampak pada pegawainya, terutama dalam hal penyelesaian target dalam pekerjaan yang diberikannya. Berdasarkan data hasil penelitian per indikator lingkungan kerja kerja ini pegawai ini yang merupakan hal yang harus diperhatikan oleh organisasi.

\section{Tabel 4. Hubungan antara lingkungan kerja dengan kinerja}




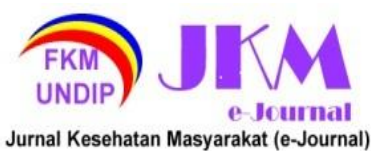

pengalaman kerja $(\mathrm{p}=0,001)$ dan lingkungan kerja $(\mathrm{p}=0,002)$ dengan kinerja pegawai di Puskesmas Sragen.

\section{SARAN}

1. Puskesmas Sragen seharusnya lebih memperhatikan sikap kerja pegawainya dalam aspek kognitif, aspek afektif dan aspek konatif. Yang diharapkan dapat mengakibatkan terciptanya kinerja pegawai yang lebih baik. Dengan demikian, kinerja pegawai tentunya akan mengalami peningkatan yang efektif.

2. Puskesmas Sragen seharusnya lebih memperhatikan kebutuhan pegawainya yang dapat meningkatkan motivasi kerja pegawai dengan cara memberikan penghargaan dan pengakuan atas hasil kerja pegawai yang baik, memberikan kesempatan pegawai untuk berkembang, dan pemberian insentif atas hasil kerjanya. Yang diharapkan dapat mengakibatkan terciptanya kinerja pegawai yang lebih baik. Dengan demikian, kinerja pegawai tentunya akan mengalami peningkatan yang efektif.

3. Puskesmas Sragen diharapkan untuk meningkatkan pengalaman kerja pegawai dengan memberikan pelatihan untuk menambah pemahaman terhadap pekerjaannya. Sehingga pengetahuan dan ketrampilan pegawai senantiasa meningkat. Hal tersebut sangat penting untuk menunjang kinerja dari pegawai. Dengan pemahaman akan pekerjaannya, pegawai dapat melakukan pekerjaannya dengan lebih mudah akan berdampak pada kinerja pegawainya.

4. Dalam penelitian yang dilakukan oleh peneliti, masih terdapat banyak kekurangan. Oleh karena itu, peneliti mengharapkan untuk peneliti selanjutnya untuk bisa menyempurnakan dengan menambah faktor lain yang berkaitan dengan penelitian ini untuk meningkatkan kinerja.

\section{DAFTAR PUSTAKA}

1. Valerisha, A., \& Putra, M. A. Pandemi Global COVID-19 dan Problematika Negara-Bangsa: Transparansi Data Sebagai Vaksin Sociodigital? Jurnal Kesehatan Masyarakat; 2020.

2. Ilpaj, S. Analisis Pengaruh Tingkat Kematian Akibat Covid-19 Terhadap Kesehatan Mental Masyarakat di Indonesia. Jurnal Pekerjan Sosial, 2020; 16-28.

3. Kuria, R. N., \& Nzuve, P. S. Factors Perceived To Infuence Employees Performance; A Case of Kenyan State Law Office. Journal of Bussiness \& Economic Policy; 2018.
4. Gibson, \& James, L. Organisasi, Perilaku, Struktur dan Proses. Jakarta: Erlangga; 2000.

5. Robbins, P. S., \& Jugge, T. A. Perilaku Organisasi. Jakarta: Salemba Enpat; 2006.

6. Azwar, S. Sikap Manusia. Teori dan Pengukurannya. Yogyakarta: Pustaka Belajar; 2011.

7. Zamroni, A. K. Pengaruh Penempatan Kerja, Sikap Kerja, dan Lingkungan Kerja Terhadap Kinerja Karyawan BRI Syari'ah Kantor Cabang Semarang dengan Kepuasan Kerja sebagai Variabel Moderating. SKRIPSI, 2020; 116-117.

8. Hernika. Faktor-Faktor yang Berhubungan dengan Kinerja Perawat di Ruang Rawat Inap RSUD Cut Nyak Dhien Meulaboh Tahun 2015. SKRIPSI; 2016.

9. Fauzi, L. I. Pengaruh Motivasi Kerja dan Pengalaman Kerja Terhadap Kinerja Karyawan (Studi Kasus PT. Adi Satria Abadi). SKRIPSI, 2018; 64-65.

10. Mangkunegara. Evaluasi Kinerja SDM. Bandung: Refika Aditama; 2004.

11. Jefrison. Faktor-Faktor yang Berhubungan dengan Kinerja Pegawai Puskesmas Pariaman Tahun 2016. SKRIPSI; 2017.

12. Foster Bill. Pembinaan untuk Peningkatan Kinerja Karyawan. Jakarta: PPM Kanisius; 2015.

13. Surjosuseono, D. Pengaruh Lingkungan Kerja dan Motivasi Kerja Terhadap Kinerja Karyawan pada Bagian Produksi UD Pabrik ADA Plastic. AGORA, 2015; 175-179.

14. Hanaysha, J. (2016). Examining the Effects of Employee Empowerment, Teamwork, and Employee Training on Organizational Commitment. Procedia-Social and Behavioral Commitment, 298-306. 